\title{
Effect of $17 \alpha$ methyl testosterone on sex reversal of Oreochromis niloticus fry
}

\author{
Elsadig A. Hagar ${ }^{1 *}$, Eitdal M. Tom ${ }^{1}$ and Namarig B. Ahmed ${ }^{1}$ \\ ${ }^{1}$ Department of Fisheries, College of Natural Resources and Environmental Studies, University of Bahri. Sudan. \\ *Corresponding Author: Elsadig A. Hagar, Department of Fisheries, College of Natural Resources and Environmental Studies, University of \\ Bahri. Sudan.
}

Received date: March 13, 2021; Accepted date: March 28, 2021; Published date: March 30,2021

Citation: Elsadig A. Hagar, Eitdal M. Tom and Namarig B. Ahmed (2021) Effect of $17 \alpha$ methyl testosterone on sex reversal of Oreochromis niloticus fry. J, Biotechnology and Bioprocessing. 2(3); DOI: 10.31579/2766-2314/033

Copyright: (C) 2021, Elsadig A. Hagar. This is an open access article distributed under the Creative Commons Attribution License, which permits unrestricted use, distribution, and reproduction in any medium, provided the original work is properly cited.

\begin{abstract}
The effect of oral application of three concentrations of $17 \alpha$ methyl testosterone (17 $\alpha$-MT) in sex reversal of Oreochromis niloticus fry was studied. About 1,200 day one $O$. niloticus larvae with an average weight of $0.002 \mathrm{~g}$ distributed into 12 plastic container (each $14 \mathrm{~L}$ capacity). The experiment consisted of four treatments and three replicates for $17 \alpha$-MT application in stage one, and 12 happa $(1 \mathrm{~m} \times 1 \mathrm{~m} \times 1 \mathrm{~m})$ in stage two for fry rearing. The male $\%$ increased significantly $(\mathrm{p}<0.05)$ with increase of $17 \alpha$-MT concentration. $\mathrm{T}_{1}(63 \%)$ yielded $84 \% ; \mathrm{T}_{2}$ $(78.3 \%)$ yielded $87 \%$ and $\mathrm{T}_{3}(86.7 \%)$ yielded $(89 \%)$. Survival rates significantly decreased $(\mathrm{p}<0.05)$ with the increase of $17 \alpha$-MT level ( $\mathrm{T}_{3}, \mathrm{~T}_{2}$ and $\mathrm{T}_{1}$, respectively). The proved that oral application of $17 \alpha-\mathrm{MT}$ is useful in sex reversal and production of male of $O$. niloticus.
\end{abstract}

Keyword: oral, methyl testosterone, sex reversal, fry, oreochromis niloticus

\section{Introduction}

Oreochromis niloticus is considered one of the most important freshwater species cultured all over the world [18]. According to [13] $O$. niloticus is characterized by fast growth, resistance to high temperature and diseases, adaptability to low water quality, and suitability to different farming systems. One of the problems associated with its culture is excessive breeding [32]. As the male tilapias grow faster than females, culture of a mono-sex reduce the fish breeding and divert less energy into reproduction [7]. However, the male tilapia can be produced by manual sexing, environmental manipulation, hybridization, triploid, pulse electric field inductions [30]; genetic manipulation or hormonal sex reversal [7]. None of these methods can achieve $100 \%$ sex reversal and thus a combination of methods is suggested [9]. According to [31] induction of sex reversal may serve as a valuable tool to produce mono-sex populations for the aquaculture industry. According to [21], sex reversal by $17 \alpha$-MT application in feed is probably the most effective and practical method for the production of all male O. niloticus. However, this technique require same age group of fish in early stage to ensure good reversal percentage; and easily lowering percent when natural feed is available in production environment [22]. Long time required in nursery stages results in high rate of mortality [4]. Oral application (egg and fry immersion) shows gave the best results, with a higher success rate and without the risk to employees due to contact with the $17 \alpha$-MT during the preparation of the feed [26]. Some other advantages of these techniques are: it takes less period of time, less water quality and quantity is needed and no influences from fish feeding behaviour [4]. Studies on sex reversal by oral immersion of $17 \alpha$ methyl testosterone are very few and focused mainly on eggs instead of fry such as in Coho salmon Onchorynhus kisutch [28]; Oreochromis mossambicus [32]; O. niloticus [15 and 16]. [10] and [27] reported that, the masculinization technique by oral administration of $17 \alpha$-MT is the most common method used in the Philippines for the production of all male tilapia [3] revealed that about $88 \%$ male were resulted when immersion of 2 day old eggs in $500 \mu \mathrm{g} / \mathrm{L}$ of methyl testosterone at 24 hours. [5] used methyl testosterone at 200$400 \mu \mathrm{g} / \mathrm{L}$ and immersed new hatched larvae for $2 \mathrm{~h}$ duration per week resulted in $82-100 \%$ males. $90 \%$ male were obtained by [8] when he immersed 21-30 day post-hatched tilapia fry in $5 \mathrm{mg} / \mathrm{L}$ methyl testosterone for 3 days. However, [14] obtained $79.3 \%$ males when immersing the newly hatch tilapia in $200 \mu \mathrm{g} / \mathrm{L}$ methyl testosterone in 13 days [15] showed that $3-\mathrm{hr}$ exposure of $O$. niloticus fry at 10 and 13 days in methyltestosterone at $500 \mathrm{mg} \mathrm{1-1}$ getting more than $93 \%$ male. The objective of this research is to determine the efficiency of orally application method of $17 \alpha-\mathrm{MT}$ on sex reversal; growth and survival of $O$. niloticus.

\section{Materials and Methods}

Source of $O$. niloticus larvae

The experiment was conducted in a private hatchery facilities located at Asellait Agriculture Scheme (17 km Khartoum North). Newly hatched 1200 larva (day one) $O$. niloticus with an average body weight of $0.02 \mathrm{~g}$ were collected from the hatchery.

\section{Feed preparation and impregnation}

Commercial feed of $44 \%$ crude protein was impregnated by $17 \alpha$ methyl testosterone (17 $\alpha$-MT). A stock solution of $17 \alpha$-MT was made by mixing and dissolving $0.50 \mathrm{~g}$ of $17 \alpha-\mathrm{MT}$ in $3 \mathrm{ml}$ absolute alcohol, and then add $9 \mathrm{ml}$ of distilled water. The stock solution was used as follows: a $63 \%$ to be added to rearing water (T1); preparation of two impregnated feeds (T2 
at $78.3 \%$ and T3 at $86.7 \%$ ). The control with $0.0 \% 17 \alpha$-MT. Preparation of impregnated feed followed [2 and 8]. The prepared impregnated feeds were spread to obtain a $3-5 \mathrm{~cm}$ flakes under shade and stored in refrigerator when dry. The amount of food offered was $0.5 \mathrm{~g} /$ fish/day.

\section{The experiments}

$17 \alpha$-MT application stage for 28 days

Twelve rectangle plastic containers (each $16 \mathrm{~L}$ capacity) were used to create four treatment $\left(T_{1}, T_{2}, T_{3}\right.$ and control) and three replicates $R_{1}-R_{3}$ (Figure 1). To each tank filled with $12 \mathrm{~L}$ chlorine free water, 100 day one larvae $(O$. niloticus) from incubation jars were stocked. Each tank was covered with a fine mesh. $\mathrm{T}_{1}$ larvae were subject to $17 \alpha$-MT at $63 \%$ in rearing water. After adding the $17 \alpha$-MT to the tanks, facilitate alcohol evaporation at room temperature by using air stone diffuser.- $\mathrm{T}_{2}$ larvae were subject to feed impregnated with $17 \alpha-\mathrm{MT}$ at $78.3 \%$. T3 larvae were subject to feed impregnated with $17 \alpha-\mathrm{MT}$ at $86.7 \%$ and kept at the same time in rearing water treated with $17 \alpha-\mathrm{MT}$ at $63 \%$. The control was deprived from $17 \alpha-\mathrm{MT}(0.0 \%)$.

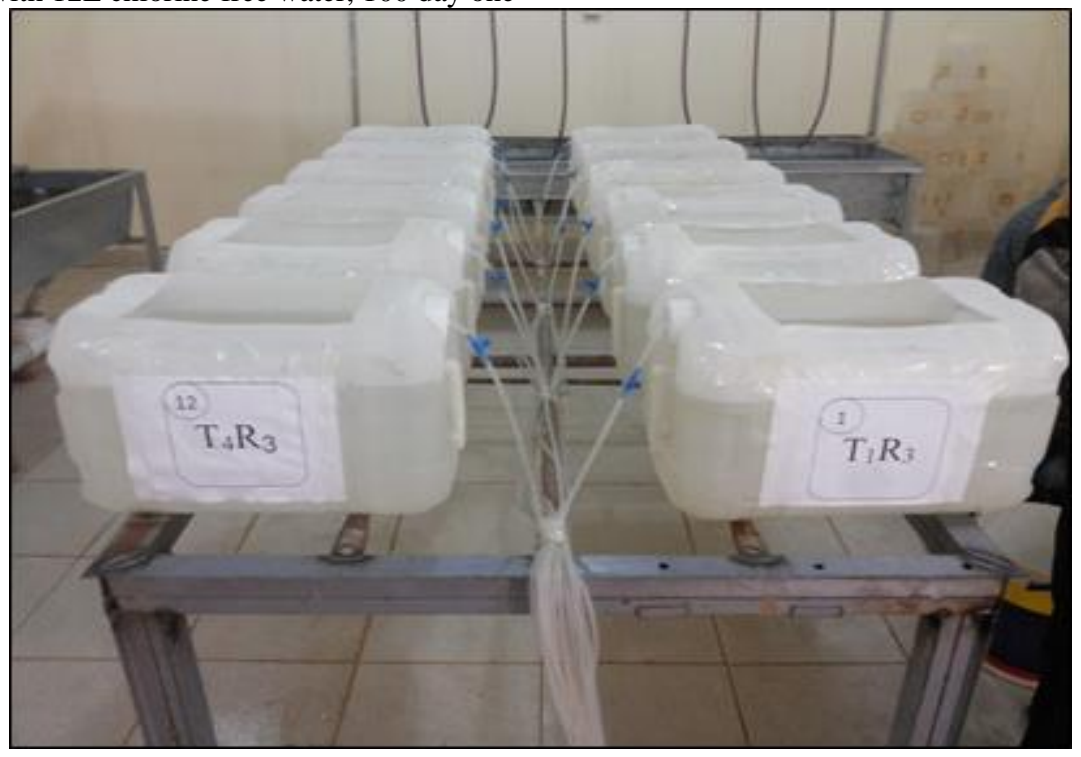

Figure 1. Experimental setup for $17 \alpha$-MT application stage.

\section{Larvae rearing stage}

Twenty eight days larvae were reared in $1 \times 1 \times 1 \mathrm{~m}$ plastic happa (800 micron mesh size, P), The 12 happas were fixed at earthen pond. Larvae were randomly distributed in four treatment and three replicates (Figure 2 ). The feeding protocol was as in $17 \alpha$-MT.

In both experiments, the mortality, feed quantity, water siphoning and exchange were monitored daily.

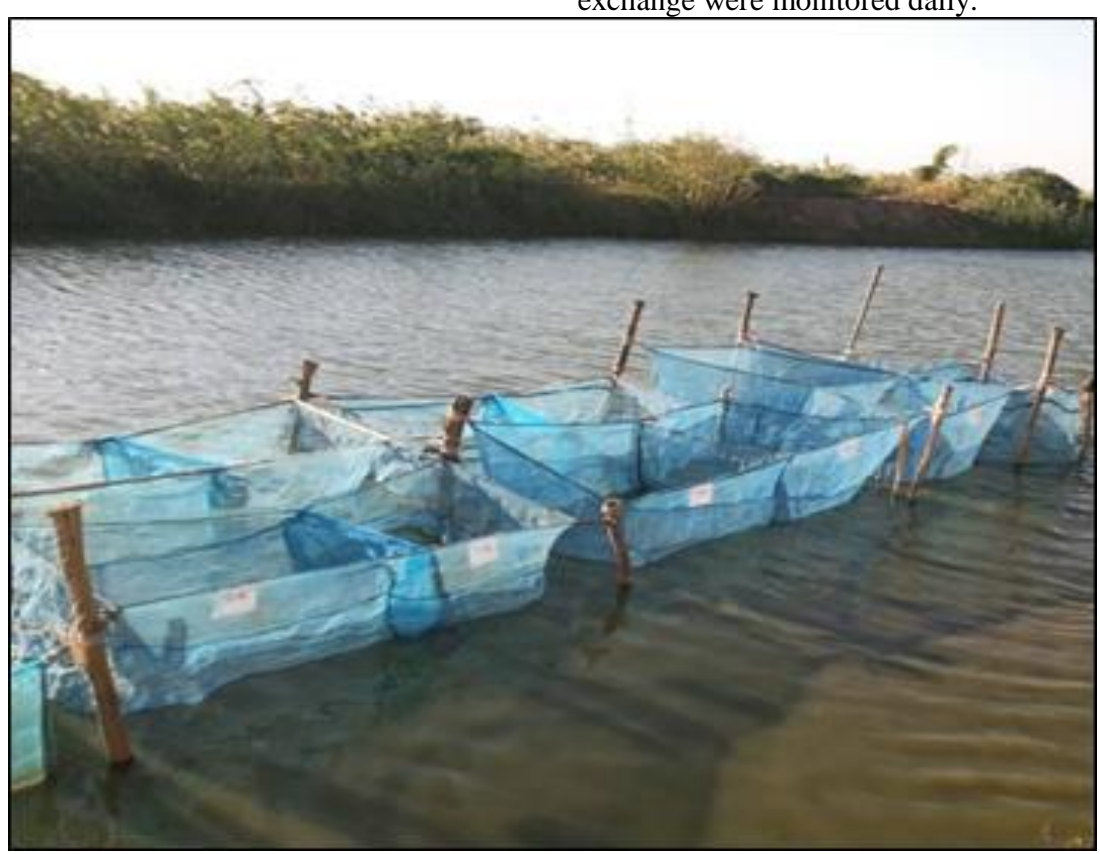

Plate 2. Experiment. 


\section{Sex ratio determination}

At the end of rearing stage, the sex of each fry was determined following [17].

\section{Data analysis:}

Data was analyzed using SPSS programme (version 22). Results were compared with one-way ANOVA and considered significant at $\mathrm{p}<0.05$. Duncan's test were used to identify statistically significant differences among treatment means.

\begin{tabular}{|l|c|c|c|c|c|}
\hline Parameter & $\mathrm{T}_{1}$ & $\mathrm{~T}_{2}$ & $\mathrm{~T}_{3}$ & Control & $\mathrm{F}$ \\
\hline Initial weight & $0.0193^{\mathrm{a}} \pm 0.002$ & $0.0177^{\mathrm{a}} \pm 0.004$ & $0.0173^{\mathrm{a}} \pm 0.003$ & $0.0193^{\mathrm{a}} \pm 0.002$ & $0.539^{\mathrm{NS}}$ \\
\hline Final weight & $0.050^{\mathrm{a}} \pm 0.01$ & $0.075^{\mathrm{c}} \pm 0.00$ & $0.057^{\mathrm{a}} \pm 0.00$ & $0.062^{\mathrm{b}} \pm 0.00$ & $13.365^{*}$ \\
\hline Weight gain & $0.031^{\mathrm{a}} \pm 0.012$ & $0.057^{\mathrm{b}} \pm 0.004$ & $0.040^{\mathrm{a}} \pm 0.003$ & $0.043^{\mathrm{a}} \pm 0.002$ & $9.479^{*}$ \\
\hline FCR & $13.290^{\mathrm{a}} \pm 2.370$ & $14.080^{\mathrm{a}} \pm 2.792$ & $13.639^{\mathrm{a}} \pm 1.207$ & $11.728^{\mathrm{a}} \pm 0.425$ & $0.833^{\mathrm{NS}}$ \\
\hline Survival rate \% & $90.33^{\mathrm{c}} \pm 2.31$ & $74.67^{\mathrm{b}} \pm 4.62$ & $53.67^{\mathrm{a}} \pm 2.31$ & $68.00^{\mathrm{b}} \pm 10.15$ & $20.589^{*}$ \\
\hline
\end{tabular}

Means with similar superscripts in a raw are statistically insignificantly different ( $>>0.05)$; those with different superscripts are statistically significantly different $(\mathrm{p}<0.05)$.

\section{Results and discussions}

\section{Growth performance and survival rate:}

Analysis of variance (Table 1) showed significant effects of $17 \alpha$-MT application methods $(\mathrm{p}<0.05)$ in final weight, weight gain and survival rate, while initial weight and FCR showed insignificant differences ( $p>0.05$ ). The lowest survival of $53.67 \%$ occurred at the $\mathrm{T}_{3}$ and the highest weight gain $(90.3368 \%)$ was obtained at $\mathrm{T}_{1}$.

\section{Table 1. Growth performance and survival rate of O. niloticus larvae under treatments of (T1, T2, T3 and control). (Means \pm SD). *Significant, NS: not significant.}

\section{Larvae rearing stage}

Table 2 showed no significant differences $(p>0.05)$ in initial weight, final weight and weight gain of the four experimental groups in happas. There is a significant difference $(\mathrm{p}<0.05)$ in FCR and survival rate percentages and highly significant difference $(\mathrm{p}<0.01)$ in male production.

\begin{tabular}{|l|l|l|l|l|l|}
\hline Parameter & \multicolumn{1}{|c|}{$\mathbf{T}_{\mathbf{1}}$} & \multicolumn{1}{|c|}{$\mathbf{T}_{\mathbf{2}}$} & \multicolumn{1}{|c|}{$\mathbf{T}_{\mathbf{3}}$} & \multicolumn{1}{|c|}{ control } & \multicolumn{1}{|c|}{$\mathbf{F}$} \\
\hline Initial weight & $0.150^{\mathrm{a}} \pm 0.000$ & $0.075^{\mathrm{a}} \pm 0.000$ & $0.057^{\mathrm{a}} \pm 0.000$ & $0.062^{\mathrm{a}} \pm 0.000$ & $0.00^{\mathrm{NS}}$ \\
\hline Final weight & $3.521^{\mathrm{b}} \pm 0.532$ & $3.232^{\mathrm{b}} \pm 0.845$ & $3.327^{\mathrm{b}} \pm 0.339$ & $1.954^{\mathrm{a}} \pm 0.692$ & $3.83^{\mathrm{NS}}$ \\
\hline Weight gain & $3.421^{\mathrm{b}} \pm 0.614$ & $3.157^{\mathrm{b}} \pm 0.845$ & $3.270^{\mathrm{b}} \pm 0.339$ & $1.892^{\mathrm{a}} \pm 0.692$ & $3.52^{\mathrm{NS}}$ \\
\hline FCR & $4.696^{\mathrm{ab}} \pm 0.803$ & $6.092^{\mathrm{b}} \pm 0.963$ & $3.653^{\mathrm{a}} \pm 0.771$ & $8.607^{\mathrm{c}} \pm 0.695$ & $20.79^{*}$ \\
\hline Sur \% & $86.667^{\mathrm{b}} \pm 5.132$ & $78.333^{\mathrm{b}} \pm 10.066$ & $63.000^{\mathrm{a}} \pm 9.165$ & $78.667^{\mathrm{b}} \pm 4.163$ & $5.13^{*}$ \\
\hline Male \% & $84.000^{\mathrm{b}} \pm 3.000$ & $87.000^{\mathrm{b}} \pm 2.000$ & $89.000^{\mathrm{b}} \pm 1.000$ & $56.667^{\mathrm{a}} \pm 4.933$ & $71.76^{* *}$ \\
\hline
\end{tabular}

Means with similar superscripts in a raw are statistically insignificantly different $(\mathrm{p}>0.05)$; those with different superscripts are statistically significantly different $(\mathrm{p}<0.05)$.

\section{Table 2. Growth performance and survival rate of treated O. niloticus larvae fed commercial feed. (Means \pm SD). NS: not significant, *significant} and $* *$ highly significant differences.

\section{Sex determination}

The sex identification and determination of fish in general and $O$. niloticus in particular are based on morphological characteristic of the fish which is difficult to apply in early fry stage [1]. According to [17], [12], [16] and [1] staining squashed gonads by acetocarmine can differentiate clearly testes from ovaries. The present study used the squash technique and found intersex confirming the results obtained by [1] who observed oocytes scattered among testicular tissue.

In the present study highest $O$. niloticus male production $(89.00 \%)$ occurred at $\mathrm{T}_{3}$, followed by $87 \%$ in $\mathrm{T}_{2}$ and $84 \%$ in $\mathrm{T}_{1}$. All these were highly significantly $(\mathrm{p}<0.01)$ different from $56.67 \%$ in the control. At 60 mg $17 \alpha$-MT dose, the maximum male $O$. niloticus was $93.3 \%$ by [19] of for 21 days; [11] reported $93.7 \%$ males after 28 days; [8] observed 95\% males after 21 days [25] found treatment with $60 \mathrm{mg} / \mathrm{kg}$ of $17 \alpha$-MT diet resulted in $80 \pm 3.34 \% \%$ males. [4] obtained $85 \%$ O. niloticus males when egg and larvae were immersed in $1000 \mu \mathrm{g} / \mathrm{L}$ of $17 \alpha-\mathrm{MT}$. [12] found that the highest dose of $90 \mathrm{mg} 17 \alpha$-MT resulted in significantly lower $(\mathrm{p}<0.05)$ male proportion (59.3\%).[28] by adding $400 \mathrm{ug} / \mathrm{L} 17-\alpha$ MT in rearing water of Oncorhynchus kisutch obtained $73.1 \%$ males. [29] found that in Oreochromis spilurus the highest proportion of males (90.3\%) was given by $70 \mathrm{mg} / \mathrm{kg}$ of $17 \alpha-\mathrm{MT}$. [23] used a dose rate of $75 \mathrm{mg} 17 \alpha-\mathrm{MT}$ in feed and recorded a maximum $O$. mossambicus male production of $98.09 \%$ [33]. Administration of 17 $\alpha$-MT effectively masculinized Rhamdia quelen fry; however, the lowest dose of $60 \mathrm{mg} / \mathrm{kg}$ of feed is recommended, since higher doses have inhibitory effects on gonadal development in both sexes [20] found that Labeo rohita testis produced more male population and can safely and effectively replace the synthetic $17 \alpha-\mathrm{MT}$.

The minimum $O$. niloticus male proportion of $83.3 \%$ was recorded for a dose rate of $50 \mathrm{mg} 17 \alpha-\mathrm{MT}$ by [19] and by [24] for 25 days [23] who got lower male proportion (79.38\%) for the same dose in $O$. mossambicus for the same duration of treatment.

According to [16] $17 \alpha-\mathrm{MT}$ is rapidly absorbed and metabolized resulting in increased protein synthesis, promoting of growth and enhancement of masculinization. The present study on sex reversal of $O$. niloticus by larvae immersion reduced the duration of the treatment and decreased the cost of $17 \alpha$-MT used. This result is in line with [31]. The result of [19] showed that no intersex was found in the treated groups and control groups which is similar to the earlier findings of [11]. But contradictory results were reported by [24] where intersex (6.2\% for $50 \mathrm{mg} \mathrm{MT} \mathrm{kg-1)}$ and $(2.7 \%$ for $60 \mathrm{mg}$ MT kg-1) was obtained in these dose rate when the hormone was given for a period of 25 days. [25] found treatment with $60 \mathrm{mg} / \mathrm{kg}$ of $17 \alpha-\mathrm{MT}$ resulted in $20.0 \pm 7.8 \%$ intersex in O. niloticus.

\section{Survival rate and growth:}

The present found that the mean survival rate $(86 \%)$ was significantly higher in oral $17 \alpha$-MT application and lowest (63\%) in mixed application. Comparison between sex reversal and weight gain showed that the FCR in a descending order as follows: control (8.6)>feed 
application (6.1)> oral group (4.7) and > mixed application method (3.7). The finding is in agreement with [6] mono-sex tilapia culture.

The minimum $O$. niloticus male proportion of $83.3 \%$ was recorded for a dose rate of $50 \mathrm{mg} 17 \alpha-\mathrm{MT}$ by [19] and by [24] for 25 days [23] who got lower male proportion $(79.38 \%$ ) for the same dose in $O$. mossambicus for the same duration of treatment.

The survival rate and sex reversal \% seems to be $17 \alpha-\mathrm{MT}$ dose and duration dependent and species related [11] reported $80 \%$ survival in the control group than in 17a-MT treated groups. On the contrary, [8] and [19] reported that 17a-MT administration has no significant effect on survival of related $O$. niloticus; which is in line with [17] findings in Oreochromis aureues.

\section{Conclusion}

The survival rate and sex reversal $\%$ seems to be $17 \alpha-\mathrm{MT}$ dose and duration dependent and species related. This study revealed significant male production rate of $O$. niloticus was achieved by immersion of larvae increasing with increase of $17 \alpha$-MT concentration. The survival rate significantly decreased with the increased of the $17 \alpha$-MT level. Further studies should be carried out to determine the optimum dose and duration to achieve $100 \%$ masculinization.

\section{Acknowledgement}

We are grateful to Prof. Zuheir N. Mahmoud, Department of Zoology, Faculty of Science, University of Khartoum, for critically reading the manuscript.

\section{References}

1. Afonso, L.O.B.; Wassermann, G.J.; Oliveira, R.T. (2001) Sex reversal in Nile tilapia (Oreochromis niloticus) using a nonsteroidal aromatase inhibitor. Journal of Experimental Zoology, New York, v.290, p.177-181.

2. Ahmed, Reem, A. (2013) Masculinization of Nile tilapia (Oreochromis niloticus) using synthetic androgen 17 $\alpha$-Methyl Testosterone. B. Sc. (hons) Fisheries Science, Sudan University of Science and Technology.

3. Anonymous. (2002) Cleaner technique to produce all-male tilapia. Asian Aquaculture Magazine. July/August. 6 p.

4. Arriesgado, D. M., Vicente H. J. and Vicente D. A. (2011) Production of Male Oreochromis niloticus GET Excel Tilapia by Egg Immersion in Methyl Testosterone Hormone. Journal of Environment and Aquatic Resources. 2: 21-33.

5. Baker, I. J., Solar, I. I., Donaldson, E. M. (1988) Masculinization of Chinook salmon (Oncorhynchus tshawycha) by immersion treatment using 17alpha-methyltestosterone around the time of hatching, Aquaculture, 72(3-4): 359-369.

6. Belton, B., Turongruang, D., Bhujel, R. and Little, D. C. (2009) The history status and future prospect of mono-sex tilapia culture in Thialand. Aquaculture Asia, 16-19.

7. Bhujel, R. C. (2009) Artificial incubation, hormones sex reversal promoted tilapia boom. Global Advocate. 73-75.

8. Bhujel, R. C. (2010) On-farm feed management practices for Nile Tilapia (Oreochromis niloticus) in Thailand. FAO Expert Consultant workshop on farm Feeding and feed management in Aquaculture.

9. Cagauan, A.G., Baleta, F.N. and Abucay, J.S. (2004) Sex Reversal of Nile Tilapia, Oreochromis niloticus L. by Egg Immersion Technique: The effect of hormone concentration and immersion time. College of Fisheries and Aquaculture Center. Central Luzon State University, Science City of Muñoz, Nueva Ecija, Philippines.10p.
10. Carrasco, L. A., Penman, D.J., Villalobos, S.A and Bromage, N. (1999).The effects of oral administration with 17 alpha methyltestosterone on chromosomal synapsis in Oreochromis niloticus (Pisces, Cichlidae). Mutat. Res. 29:430(1):87-98.

11. Celik, I., Guner, Y. and Celik, P. (2011) Effect of orallyadministered $17 \alpha$-methyltestosterone at different doses on the sex reversal of the Nile tilapia (Oreochromis niloticus, L. 1758). J. Anim. Vet. Adv. 10 (7): 853-857.

12. Donaldson, E.M.; Devlin, R.H.; Piferrer, F. (1996) Hormone and sex control in fish with emphasis on salmon. Asian Fisheries Society, Manila, v.9, p.1-8.

13. El-Sayed, A. F. M. (2006). Tilapia Culture (Wallingford: CABI Publishing) 277pp.

14. Fitzpatrick, M. S., Contreras-Sanchez, W. M., Miston, R. H., Lucero, M., Feist, G. W., Schreck, C. B. (1999). Steroid immersion for mazculinization of tilapia: Immersion for tilapia fry in MDHT. In: McElwee, K., Burke, D., Niles, M. and Egna. H. (Eds.), Sixteenth Annual Technical Report. Pond Dynamics/Aquaculture CRSP, Oregon State University, Corvallis, Oregon. pp. 73-74.

15. Gale, W. L., Fitzpatrick M. S. and Schreck. (1995). Immersion of Nile tilapia (Oreochromis niloticus) in 17-methyltestosterone and mestanolone for the production of all-male populations. In: F. W. Goetz (ed.). Proc. Fifth International Symposium on the Reproductive Physiology of Fish. Fish Symposium 95. The University of Texas at Austin, Texas, U.S.A. 117 pp.

16. Gale, W. L., Fitzpatrick, M. S. M. Lucero, W. M. ContrerasSanchez and Schreck. M. S. (1999). Masculinization of Nile tilapia (Oreochromis niloticus) by immersion in androgen. Aquaculture, 178: 349-357.

17. Guerrero, R. D.; Shelton W. L. (1974). An acetocarmine squash technique for sexing juvenile fishes. The Progressive FishCulturist, v.36, p.56.

18. Isabel, R. B.; Sara, L.; Rhaul, O.; Inês, D.; Amadeu, M. V. M. and António, J. A. N. (2013). Determination of $17 \alpha$ Methyltestosterone in Freshwater Samples of Tilapia Farming by High Performance Liquid Chromatography. American Journal of Analytical Chemistry, 4, 207-211.

19. Jensi, A.; Marx, K. K.; Rajkumar, M.; Shakila, R. J. and Chidambaram, P. (2016) Effect of $17 \alpha$-methyl testosterone on sex reversal and growth of Nile tilapia (Oreochromis niloticus L., 1758). Eco. Env. \& Cons. 22 (3):1493-1498.

20. Khanal, N.B., M.K, Shrestha, S. Rai and R.C. Bhujel (2014) Comparative evaluation of Carp testis as an alternative to $17 \alpha$ Methyltestosterone on Tilapia sex reversal. Our Nature. 12 (1): $1-7$.

21. Little, D. C.; Bhujel, R. C. and Pham T.A. (2003). Advance nursing of mixed sex and MT-treated tilapia (Oreochromis niloticus) fry and its impact on subsequent growth in fertilized ponds. Aquaculture. 221, 265-276.

22. Mair, G. C. (1997). The problem of sexual maturity in tilapia culture. pp. 6-13. In: G. C. Mair and T. A. Abella (eds.). Technoguide on the Production of Genetically Male Tilapia (GMT), Freshwater Aquaculture Center, Central Luzon State University, Nueva Ecija, Philippines.67 p.

23. Marjani, I.; Jamili, S.; Mostafavi, P. G.; Ramin, M. and Mashinchain, A. (2009) Influence of 17-Alpha Methyl Testosterone on Masculinization and Growth in Tilapia (Oreochromis mossambicus). Journal of Fisheries and Aquatic Science, 4:71-74.

24. Mateen, A. and Ahmed, I. (2007) Effect of Androgen on Sex Reversal and Growth of Nile Tilapia (Oreochromis niloticus). Pak. J. Agri. Sci., Vol. 44(2):272-276. 
25. Osho, E. F.; Ajani, E. K.; Omitoyin; B. O. and Aniebo, V. (2014) Physical masculization and growth performance of Oreochromis niloticus placed on $17 \alpha$-methyltestosterone treated diet. Journal of Environmental Extension. Vol. 12: eISSN: 1595-5125.

26. Pandian, T. J. and Sheela S. G. (1995) Hormonal induction of sex reversal in fish (Review). Aquaculture. (138) pp 1-22.

27. Phelps, R. P. (2006) Hormone manipulation of sex. pp. 211-252. In: Lim, C. and Webster, C. D., (eds.). Tilapia Biology, Culture and Nutrition (Haworth Press, Inc., New York, London, Oxford.

28. Piferrer, F., Benfey, T. J. and Donaldson, E. M. (1994). Gonadal morphology of normal and sex reversed triploid and gynogenetic diploid Coho salmon (Oncorhynchus kisutch). J. Fish. Bio.45:541-553.

29. Ridha M.T. and Lone, K. P. (1990) Effect of oral administration of different levels of $17 \alpha$ - methyltestosterone on the sex reversal, growth and food conversion efficiency of the tilapia Oreochromis spilurus (Günther) in brackish water. Aquaculture Research. Vol. 21(4):391-397.

30. Sakshin B.; Thanyada S.; Adisorn T., Jaruwongrungsee K. and Raymond J. R. (2015) Monosex Male Sex Reversal of Nile Tilapia Eggs Using Pulse-Electric Field Inductions. Journal of Computational and Theoretical Nanoscience. Vol. 12, 1-5.

31. Srisakultiew P. and Kamonrat W. (2013) Immersion of $17 \alpha-$ methyltestosterone dose \& duration on tilapia masculinization. Journal of Fisheries Sciences. 7(4): 302-308.

32. Varadaraj, K. and Pandian, T. J. (1987) Masculinization of Oreochromis mossambicus by administration of 17-methyl-5androsten through rearing water. Current Science, 56 (9): 412413. 